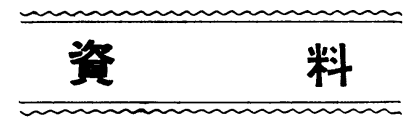

\title{
石油工業におけるケーシングの腐食*
}

\section{Casing Corrosion in the Petrolerm Industry}

\author{
J. L. Battle**
}

Corrosion, Vol. 13, No. 2, 132t 138t (1957) Feb.

\begin{abstract}
緒
兽

1954年末にアメリカ国内の石油および天然ガスを産出 している井戸の数は 514,808 本である。石油の生産高は $2,312,212,000$ バレルで, 井戸 1 本当り $12 \cdot 3$ バレルの 石油を毎日堀り出している計算になる。これらの井戸の 内約 $60 \%$ は 15 年以前に発見されたものであり, 約50 $\%$ は 20 年以前に発見されている1)。操業中のケーシン グパイプ (casing string) の失策 (failure) が起り得る が，最近までたいして問題にされていなかった。しかし 掘さくされた穴を維持することを目的としたこの薄い壁 の部分が油井の最も重要な構造材料であることを考えれ
\end{abstract} ば，問題にしないのはむしろ奇異に思われる。

石油工業の初期のごとく, 高生産率で速く涸渴してし まうようではケーシングの腐食による失策にたいした関 心を持たないのも無理からぬことであったろ5。しかし 油田の産油の寿命を長びかせ, できるだけ地中の油を堀 り出そうとして産油量の制限, より科学的生産方法の適 用および二次回収方法の重要性等に意を用いるようにな ってきて，ケーシングの腐食による失策が石油工業にお ける重大閏題となってきた。

14 の主な会社の代表者も加わっている NACE（National Association of Corrosion Engineers 全米防錆 技術協会), $\mathrm{T}-1 \mathrm{H}$ 分科委員会 (石油のケーシングパイ プの腐食関係）が最近ケーシングの腐食について調査を 行っている。関係会社で操業中の 30 の油田, 51, 462 本 の油井について 1949 年から 51 年までの 3 年間の調査に よると, 総計 235 カ所のケーシングの失策が起ってい る。そうしてこれら 235 本の修理費用は $1,343,317$ ド にものぼっている。これと全く同じ頻度でもってこれ以 外の油田にも失策が起るとすれば, その数は 1,294 にも のぼり修理費は750万ドルにも達するであろ5。この数 字は産油できない間の損失を含んでいないし，また今日

* 訳者 吉野努 鹿応義熟大学工学部 (日吉)

** Humble Oil and Refining Company, Houston, Texas.
の掘さく費用では再堀さくするには不利である油井は放 棄してしまうが，この放棄を早めてしまう損失をも含ん でいない。ケーシング腐食の問題についての解決は将来 産油の価格に重大な関係をるつことは明らかだろう。

\section{原因となる因子}

腐食の結果起ったケーシングの失策は腐食技術者にと ってはたいした問題ではない。実際, 環境からくる多く の因子を十分考虑すれば，ケーシングをでき得る限り長 く使用するにはいかにすればよいかがわかるのである。 一般に石油のケーシングパイプの失策は通常下記の原因 の一つあるいはそれ以上に基因する。

\section{外的原因}

(1) バクテリヤの侵食

（2）種々なる鉱物および流体を含む地層との接触

（3）迷走電流と地表電流 (subsurface electrical currents) による電解

（4）異種金属接触による電池作用

（5）ケーシング材の冶金学で問題になる欠陥

\section{内的原因}

（1）酸性ガス（硫化水素と炭酸ガス）による蒸気部分 の腐食

（2）酸性水による流体部分の腐食

（3）腐食性のガスーリフトに使用するガス

(4) 大気中の酸素の侵入

(5) 酸処理の際の未使用の酸

(6) 砂と流体によるェローション

（7）掘さくと完成工事中の機械的損傷

第 1 表は NACE 分科委員会の調査結果である。報告 された 235 カ所の失策の主な原因となっているものは腐 食性の水 (aggressive fresh water), 地層中の塩水抹 よび酸性ガスである。これにすぐ続くのが迷走電流によ るものである。最近の調査によればバクテリヤによる腐 食は元来考えられていたよりもはるかに重大な腐食原因 である。 Hadley 2)は微生物による腐食の重大性を説いた 
第 1 表 原 因別失策数

\begin{tabular}{|c|c|c|c|c|c|}
\hline 失 & 策 & の & 因 & 数 & $\%$ \\
\hline 迷 & 走 & 電 & 流 & 37 & 16 \\
\hline 酸 & 性 & の & 水 & 83 & 35 \\
\hline \multicolumn{4}{|c|}{ 蒸気部分の酸性カス } & 44 & 19 \\
\hline \multicolumn{4}{|c|}{ バクテリヤの侵食 } & 9 & 4 \\
\hline 塩 & 水 & （地 & 層) & 46 & 20 \\
\hline 不 & & & 明 & 10 & 4 \\
\hline そ & & の & 他 & 6 & 2 \\
\hline
\end{tabular}

首唱者であった。彼の研究は Starkey, Wight ${ }^{3)}$ と Bastin とその研究員(おおよび Beerstecher ${ }^{5}$ )の研究と同 じく十分検討されるべき問題であろう。

\section{㫏查方 法}

多くの場合，腐食技術者はケーシングの失策部分を検 查せずにその原因を分析する必要にせまられる。検査 とか研究のために損傷したパイプを回収することは，失 策の起った深さが比較的浅ければよいが深ければ通常不 可能である。ゆえに腐食技術者は失策の原因を決定した り，修理とか予防とかをいかに行うかといら勧告の基礎 とするために他の手段に頼らざるを得ない。そこで普通 下記のものを適宜調査の方法として用いている。

（1）産出した水の化学分析と出所の知れたものとの比 較

（2）産出したガスの化学分析

（3）失策の深さを見つけるパッカーテスト（Packer test)

（4）内部腐食の深さと存在を決定するケーシング測径 器 (caliper) による検査

（5）表面電流が腐食に関係寸る因子であるかどうかを 決定寸る送油管（flow line）の電流測定

\section{ケーシング蹗压図}

上記の調查方法以外の方法も最近続々発表され，その 方がもしろ広く用いられてきている。これらの内で最も 重要なのはケーシング電圧図 (casing potential log) で あろう。これはケーシング材を流れる電気量と流れの方 向とを決定するためにケーシングの一定距離間の電圧降 下の測定から得られたるのである。Ewing ${ }^{6)}$ はこの装置 を最初に用いた人達の一人で，この装置を用いた調査の 結果を発表している。

ケーシング電圧図を作るのに用いた装置は単一接点ま たは多接点のものである。電圧図を作成するには測定装 置をまず絶縁ケーブルでもって油井の中を最大測定深度 まで降ろす。最大深度まで降したとき装置を停止し，刃 型の接点をケーシングに接触し，電圧を測定する。測定 は単一接点装置の場合には接点と地表面との間にて行わ れ，多接点装置の場合には二つあるいはそれ以上の一定
間隔（普通 10，20，25 および $50 \mathrm{ft}$ ）の接点の間にて行 われる。後者すなわち多接点装置にて測定された電圧は 単一接点装置の場合に得られる值よりも非常に小さいこ そは明らかで，その值が $\mu \mathrm{V}$ の単位で測られるので高感 度の測定装置が必要である。測定された固有抵抗が鋼の， 固有抵抗からも計算されることを用いて電流量を相当高 精度で計算できる。

\section{多接点裝の利点}

単一接点も利点があるが多接点装置の利点はそれ以上 でそれについては Ewing と Bayhi'很とょって検討さ. れている。その内で最も重要な利点は次の点である。

(1) 各接点の測定值は測定される一定間隔の電流のみ. を示し，電極上の電圧降下を加味しなくてよい。

(2) 接点が 10 から 50ft とわずかしか離れていない ので熱による影響を無視できる。

（3）導線は平行で長さがほとんで等しいので外からの 影響がつり合う。

誤差の原因となるものには浸入性の浱度の高い粘着性 の水のはりつき, 腐食生成物およびパラフィンの析出等 がある。これらによる困難さは単一接点装置でも多接点 装置でもともに経験する。多接点装置は非常に高感度の 電位差計または真空管電位差計を必要とする欠点があ. る。

第 1 困と第 2 図は東テキサス油田と西テキサス油田の 油井にて括の扮の別々に単一接点装置または多接点装置 を用いて得られたものである。第 1 図は西テキサスの

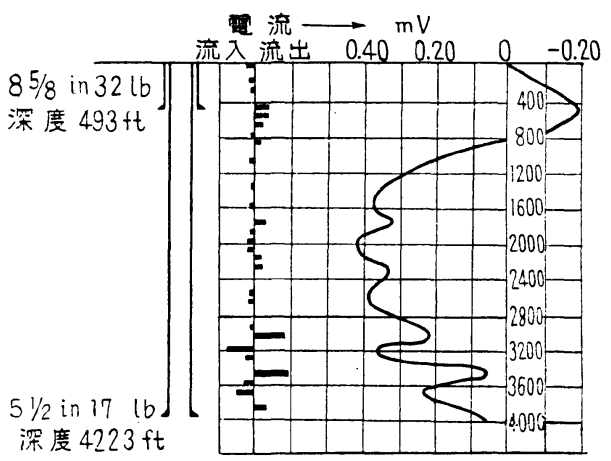

第 1 図 単一接点装置によるケーシング電圧図

Sand Hills 油田にて単一接点装置を用いて得られた電: 圧困である。これを見ると棒グラフで示されるごとく深: さ 500 から $600 \mathrm{ft}$ の所と 3,100 から $3,500 \mathrm{ft}$ の所にアノ 一ド域があることがわかる。前者の深度はコンダクター （surface casing string）が設置されている深さと大体 一致している。後者の場合はと見ると井戸の完成後14年 たって 3,119 から $3,314 \mathrm{ft}$ の間でケーシングの漏洩が 起り，セメントを圧入して修理した点と一致している。

第 2 圀は東テキサス油田にて多接点装置を用いて得ら 


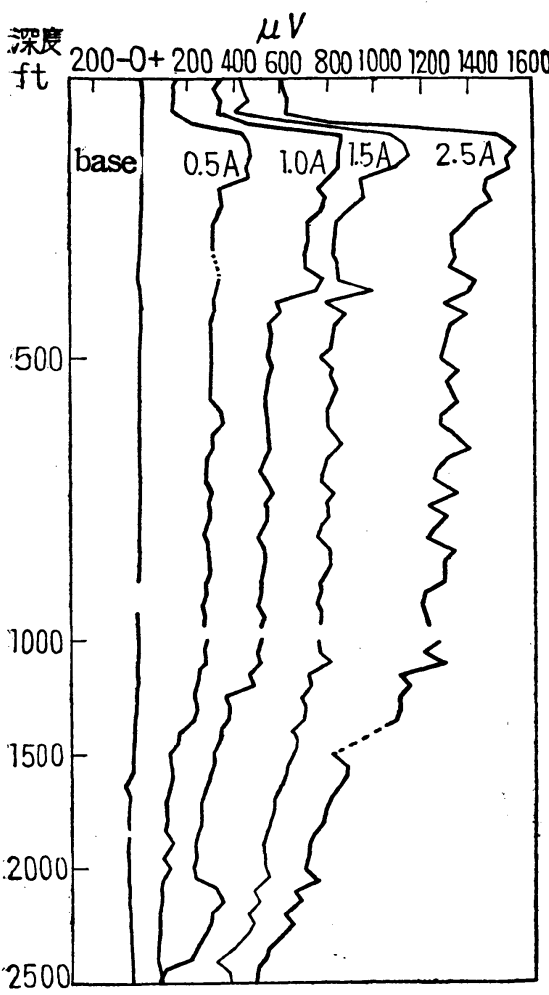

れた電圧 図であ る。基準 電圧図 (base log）を見 ると測定 最大深度 $2,500 \mathrm{ft}$ までの範 囲ではケ ーシング の電気量 はほんの わずか低 下してい るのみ で,アノ 一ド域が ないこと がわか る。油田 第 2 図 多接点装置によるケーシング電圧図

されるケーシング失策の大部分は $500 \mathrm{ft}$ より先にて起るこ とから，このような電圧図はケーシングを院性とするに 必要な電流量を決定する助けとはなるが，この油田に和 けるそれ以外の問題の研究にはたいした助けとなってい ない。この地点はケーシングパイプの電流がマイナスに なっているのだが，この状態の下に地表パイプのねもと の所のアノディックキック(anodic kick) を評価するため に行われた研究はケーシングの失策の可能性を最小に乙 た。十分な注意と判断とをもって行らなら地表電流を解 析するのにどちらの電圧図でも同じように有益である。

\section{電流霞圧曲線}

陰極防食を行うために流す必要のある電気量を決定す る方法として最近使用されだしたものに電流電圧曲線 (current-potential curve) がある。これは1931 年にす でに Britton7)によって最初に報告されている。この曲 線は補助電極との組合せにて測定した電圧と記録された 電流とを半対数方眼紙にプロットしたるのである。これ を見ると防食に必要な電流量の所で曲線が曲っている。

第 3 図は東テキサス油田で得られた代表的な電流電圧 曲線である。これの測定には Pearson-Hadley の零電 流回路を使用し，正確なる適用を期するために真空管電 位差計を必要とした。いずれの手段をとるにしても永久 にまたは長期間の防食を行うのには整流器またはマグネ

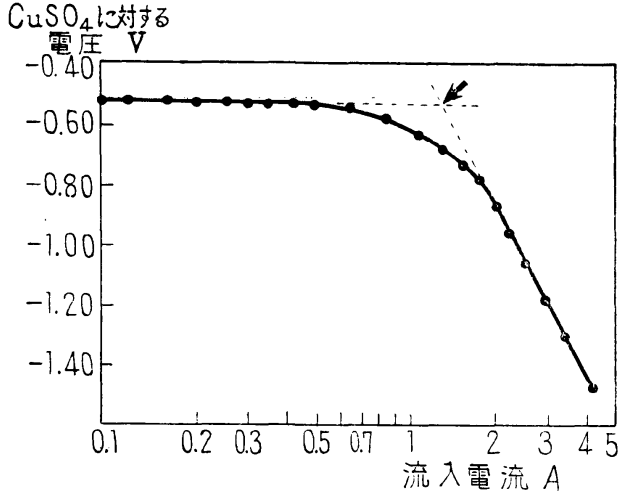

第3図電 流 電 圧曲 線

シウム陽極装置が備え付けられるだろう。そうすれば陰 極防食でもってケーシングの外部からの腐食を防ぎ得る といえる。しかしながら Sudbury, Landers および $\mathrm{Shock}^{8)}$ らは，他の人々で同じ説をとなえる人もいるの だが，ケーシングから地表パイプへの電気の流れによっ て起り得る危険性に注意をうながしている。このような 電気の流れは，それが起っている点にて石油のケーシン グパイプの腐食を促進している原因ではないか。しかし 東テキサス油畞にて 7 カ月間 $10 \mathrm{~A}$ の電流を食っていた 外径 7 in の $24 l \mathrm{~b}$ ケーシングパイプを検査してみても, 上述の原因による損傷をなんら示していない。

\section{予防方 法}

今日最も普通に実施されている予防方法は次のような ものである。

(1) 油井頭部に絶縁フランジ取付

(2) 定期的油塗装

（3）パッカー（packer）とか流体で封じられた環帯 (annulus) に気化性または不気化性腐食抑制剂の使用

(4) 激しい腐食が起りそうな場所とか現に腐食が起っ ている場所への高アルカリ泥漿の配置

（5）陰極防食の応用

（6）無機物あるいは有機物のゲル状物貿の送入

（7）防食被覆（またはセメント）の使用

\section{絕緣フランジ}

地表迷走電流（surface stray currents）を排除する ために油送管（flow line）から油井頭部と地下装置とを 絶縁するために絶縁フランジを取付けることは多くの油 田で大いに効果を上げている。Hammond と Ewing9) はロンドンでこれによる失策の数が著しく減少している ことを報告している。また Talco, Tomball 各油田にて おのおの別個にケーシングの失策の頻度が 60 70\% 減 少しているといら別のオペレーターの報告もむる。この 手段は土壤の固有抵抗が極端に低い所とか電解が地表電 流のために起っている所では効果が少ない。 


\section{防食被覆}

防食被覆の使用はさほど重要視されていない。それは 個々の場合にどんな被覆をするかを決めるのは明らかに 困難であり，また新しいパイプを設備するとき被覆に機 械的損傷を与える可能性があるからである。また良し悪 しの評価も困難な問題である。新しいやや大きめのパイ プの内表面とか上部にセメント被覆をすることはもし完 全に被覆ができるならば効果がある。

\section{高アルカリ掘さく泥獎}

高アルカリ掘さく泥漿またはゲル状物質の使用が大多 数の油田で行われている。あるオペレーターは東テキサ ス油田の多数の井戸を使って, 環帯への高アルカリ“赤” 泥浆の圧入を行った報告を寄せている。このことについ ては後章にて検討するが, 次のごとき点に問題がある。

(1) ケーシングの状態がわからないのでケーシングの 崩潰があり得ること。

(2) 目的の点に注入, 排出する流体の移動の問題

一方別のオペレーターは現今商業上用いられている有 機系ゲル状物質がバクテリヤ培養のすぐれた培養体であ るという実験報告を提出している。

\section{腐食抑制郕}

パッカーを設置し, 環帯に新しいアルカリ泥水または 原油に不気化性抑制剤を入れたものを押し込むことは酸 性ガスおよび酸性の水とによる内面の蒸気部分および流 体部分の腐食を除去する最も広く応用されている手段の 一つである。これはパッカーが油井中に残っている限り 内面腐食の問題に対する効果的でまた十分確実な解決策 であることは明瞭である。また産油中の井戸の環帯にそ のような腐食抑制剤を継続的または連続的に注入するこ とは広く実用化されているしまた効果的である。流体で 封じられた油井の環带にアンモニアのごとき気化性防食 剤の使用はよさそうに思える。最も注入方法については 詳しく研究される必要がある。

\section{陰極防食}

外面の腐食を制御するために陰極防食が用いられる が,これについては多数の人々によって大いに研究され ている。あるオペレーターは西テキサス地域の油田の 225 カ所の井户にマグネシウム陽極を使用した応用例を 報告している。また東テキサス油田にてもマグネシウム 陽極を用いた実験が行われている。地層の固有抵抗が変 化してもなんら制御の必要がないゆえにこの方法は有利 であるが，それがいかなる深さまで有効であるかは考慮 されるべき問題である。しかしながら陰極防食が 6,500 $\mathrm{ft}$ の深さにても明らかに効果があることが示されてい る。整流器, 起電陽極いずれかが直流電源として用いら れるであろう。

修 理 方 法
特別の修理方法は地域問題と関係して検討する。しか しながらこれらの技術の簡単な説明をする。最も普通に 実施されている方法は

(1) チュービングパッカー (tubing packer) の設置

(2) 内管の設置

（3）圧入セメント塗装

(4) Casing bowl assemblyによる損傷したケーシン グの切取りと取換え

(5) 失策点下のケーシングの “backing off” と“dienipples” の使用による取換え

\section{チュービングパッカー}

チュービングパッカーをケーシングの中の逸泥点の下 に設置することはケーシング失策を直す最も経済的方法 である。もしもそれで故障が起らなければ，これは油井 当り 1,000 ドルあるいはそれ以下で正常になる。しかし ながらこの方法は応急修理に次ぐ最も不満足な方法と一 般に考えられている。というのは失策点が密封されず, 腐食性流体が環帯に入り込み, チュービングとパッカー の両材質を腐食し, しばしば穴をあける産油中のパイプ の中に地中の流体が入ってしまう。

\section{内 管}

油井全体に内管 (inside liner) を敷設することは初め に設置したケーシングの大きさが大きく内管が敷設でき るような特別な地域には実用化されている。ところがあ. いにく $5 \frac{1}{2}$ in ケーシングが産油パイプとして多くの油田 に用いられている。最も掘さくのとき後日失策が起って 内管を設置しょう等と見越してそれに適するケーシング を敷設することは明らかにできない。普通のケーシング に $4{ }^{1} /{ }_{2}$ in 平面接合内管 (flush joint liner) を敷設する が,この内管は現在産油が行われているのに支障をきた さない最小の大きさのものである。内管敷設の費用は深 度とか鋼材の種類によっていろいろであるが, ぞこでも 5,000 ドルから 35,000 ドルかかるだろ5。ごく最近では 部分的に内管を敷設することによって逸泥個所を塞ぐこ とが行われている。けれどすとの操作に要する費用は全 体に内管を敷設する費用にほぼ等しい。

\section{セメント压入}

スクイズ法によってケーシング逸泥個所のセメント塗 装はそれを行う所を地層のある場所に限定してしまう方 法でもって，失策点にセメントを叙込むことである。適 用圧力によってセメントは損傷した点とその周囲の地層 に圧入され，失策の起った部分の周囲がセメントで固め られる。これは最も頻繁に用いられそうして成功した修 理の方法であり, 費用は遮蔽をするに要する段階によっ て異なるが 3,500 から 7,500ドルの間で完成する。

\section{ケーシングボウルによる取替}

Casing bowl とか patch tool assembly を用いて損 
傷したケーシングを新しいパイプを取換えるには次のよ うにして行う。失策点以下の所に柽 (plug) をはめ, 損 傷部分を機械的に切断, 回収して patch tool で新しい パイプを再設置する。この patch tool は坑の中に残っ たケーシングの位置をきめ，その上に新しいパイプが滑 り落るように設計されている。新旧両パイプの接合は casing slip と pack-off element でなされる。そうし てこれらの器具は将来の採油作業に妨害とならないよ5 にしておく。この方法はほんのわずかではあるがセメン ト圧入よりる費用がかかり，最も費用のかかる方法では あるが, 現在行われている修理方法の中で最も確実であ るので，人によってこの方法の方がむしろよいとされて いる。これは腐食したケーシングを回収して実際肉眼で 見ることのできる唯一の方法である。そのような再修理 の費用は逸泥の深さによって変る。一般に東テキサス油 田にて行われている例では用いたパイプの費用を除外し て 3,750から 4,300ドルかかっている。

\section{“バッキングオフ” (Backing Off)}

東テキサス油田にて大いに注目されている修理方法が ごく最近発達した。それは inside casing slip toolを 使用する方法である。この機械でもってケーシングは失 策点の下のつぎ目のねじを逆に回し，回らないときも無 理にあ回して抜き，そうして改良された die-nipple で もって新しいケーシングと取替える。最もこの方法は失 策の深さがそれほど大きくないときにのみ行われる。こ の方法によるケーシング修理の費用が東テキサス油田内

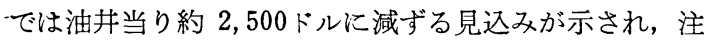
目されている。

\section{地 域 問 題}

種々な問題の中でケーシングの腐食が最も問題となっ ている五つの地域を委員会の調查対照に選び出した。そ れらを第 2 表にかかげる。

第2表 地域別腐食原因

\begin{tabular}{|c|c|c|}
\hline 地 & $\begin{array}{l}\text { 蚹食さ } \\
\text { れる面 }\end{array}$ & 原 \\
\hline 東 テ キ サ & 外 側 & 腐食性の水とバクテリヤの侵食 \\
\hline 西テキサスーニューメキシコ & 内 僋 & 酸性ガスによる蒸気部分の腐食 \\
\hline マグノリア,アーカンソー & 内 側 & 酸性ガスによる蒸気部分の腐食 \\
\hline 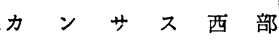 & 外 側 & Dakota water sand との接触 \\
\hline カルフォル $=ア$ (Ventura) & 外 側 & バクテリヤの侵食 \\
\hline
\end{tabular}

これら各地域は腐 食が量的に重大な問題となってい る。西テキサスーニューメキシコとマグノリア，アーカ ンソー両地域はともに酸性の原油を含むための問題に悩 .んでいる。他の三つの地域ははなはだ異なった性質の問 題である。

\section{東テキサス地域}

東テキサス油田にてケーシング失策の深度は深度が明
らかな全失策数の $80 \%$ が $400 \mathrm{ft}$ までであり， $62 \%$ が 200 から $325 \mathrm{ft}$ の間である。最も激しい腐食は 50 から $75 \mathrm{ft}$ の間で起っている。なにが第一の原因であるかにつ いては研究者間で意見が一致していない。しかしながら 腐食性の water sand が油田の大部分の地域の 150 から $300 \mathrm{ft}$ の深さに存在することが知られている。この水は 約 $100 \mathrm{ppm}$ の固体成分を含む。そうしてそれは比較的 高濃度の鉄と炭酸ガスを含有し，地表に産出された直後 の $\mathrm{pH}$ 值は 5〜6 を示す。

ケーシングが腐食を受けた地域に硫化第一鉄泥が見出 され，そうしてそこはバクテリヤによる腐食が行われて いることが示されている。送油管の電流検査とケーシン グ電圧図とはなんら重要な表面電流または地衰電流を示 していない。一般に，問題の原因を一つにしょうとする のは余りにも問題を単純にし過ぎると思われる。大体三 つの原因があると考えるのが妥当のようであるが，その 中でバクテリヤによるものが最も大きな原因であるよ5 に思われる。修理はパッカーの設置，セメントの圧入， ケーシングを切断し引上げて, casing bowl を用いて新 しいケーシングとの取替え，ケーシングの大きさの許す 限りの大きさの内管の設置等である。

ケーシングと腐食性の水との接触を断てば腐食が防げ るという仮定の下にあるオペレーターが油井のケーシン グの外側に高アルカリ泥獎を，逸泥が普通起る場所以下 の深さまで圧入した。これはまたバクテリヤによる腐食 を防ぐのではないか。ケーシングの逸泥個所が多数起っ ている地域の油井でもってこの制御方法がどの程度有効 であるかを試験した。試験に供された二つの油井は今に も放棄されそうなるのであったがこのケーシングを修復 して検查が行われた。付着した泥漿の $\mathrm{pH}$ は平常よりわ ずかしか増加しない。高アルカリ泥は地層の中に明らか にしみこんでいるがバクテリヤの侵食を止められなかっ た。泥摮を井戸の中に圧入するときの作業上の問題は晩 泥の起り易い地層を通りぬけていながら腐食を防ぐべく 十分なる深さまで泥漿を送らなければならないという問 題であった。 $150 \mathrm{lb} / \mathrm{in}^{2}$ の圧に抗して揚水できる小型口 ータリーポンプが泥漿圧入のために用いられた。この圧 力が泥獎を厤入するのに不十分でもっと大きな玨が必要 な場合にはチュービングパッカーが油井に取付けられ， 泥漿が往復動ポンプで送入されて圧をバランスさせ，ケ ーシングの崩潰を防いでいる。このようにして十分満足 な圧力が得られても泥漿が減少して地層を浅くしてしま い, 二つの井戸の実験ともかんじんの望んだ深さまで泥 獎を圧入することができかねた。ケーシングの外側に高 アルカリ泥墏の圧入の費用が油井当り 200 ドルであると 見積られる。泥嶈圧入の状態を見るために放射性元素々 $r$ 線測定装置を用いて行った五つの井戸の実験がある。 
そのような装置を用いた結果これらの実験の費用は油井 当り約 700 トルである。

陰極防食は可能性のある地域にて多くのオペレーター に大きな関心をすたれており，装置第 1 号が設置され， 注目の的となっている。

\section{西テキサスーニューメキシコ地城}

ケーシングの失策は近年西部テキサスーニューメキシ コ地域にはびこってきたので産油業者は大恐こうをきた している。調査の結果ケーシングの失策はAdair, Block 31, Hobbs, Levelland, Means, Seminole, Slaughter および Wassom 油田に広く起っていることが明らかに なった。これらの油田の多くは産油能力をフルに動かし ているので，なにか事故があればそれだけ油の損失にな る。ある会社が修理と今までの仕事の経験をもとにして 行った見積であるが，失策の予防手段を行わなければ油 井だけで 500万ドル以上す損をすることになる。

産油会社との共同研究にて失策の主原因として電池作 用を除去した。外面の孔食の深度とケーシング電圧図と の関連性は次の点で大変よく一致している。すなわち地 表電流の大部分は地表すぐ下のパイプの固定個所から逃 げているが，完全に逃げている場合は報告されている地 域ではまれである。実際, 引上げられたケーシングパイ プを調べると多くは外部からの腐食を受けてはいるがわ ずかである。

本地域の一つの油田は例外であるが，バクテリヤの侵 食によるものは見つからない。取出されたパイプのカリ パー検査と肉眼による検査によると油井の蒸気部分のみ が主として腐食していることがわかる。腐 食の原 因は water sand の側ではなく反対側のケーシングの冷たい 壁に水蒸気が凝縮するためと考えられる。最もこの中に は炭酸ガス, 硫化水素等の酸性ガスが存在する。凝縮し た水の酸性度は環帯に存在する全圧と酸性ガス濃度との 函数であると信じられている。数人の主任オペレーター が油井中の酸性ガス圧力履歴と腐 食 量との関係を調べ た。これら予備研究が行われて腐食抑制計画に対する適 当な案ができ上がった。

現在最も広く用いられている腐食抑制方法は次のごと くである。まず初めはチュービングパッカーを設置し環 帯に原油 100 バレル当り抑制剤 1 または 2 ガロンを含 み，水を含んでいない原油を押し込むことである。第 2 の方法はアンモニヤガスまたはアンモニア水のような揮 発性の抑制剂を流体で封じられた環带に注入することで ある。1 回分の薬品の注入後 9 カ月たって環帯の頭部に アンモニア蒸気が存在していたという報告がある。吸収 型または湿式型の抑制剂をポンプ系統とかガスリフト井 に連続的に入れたりまたは断続的に入れたりした実験む 行われている。この方法はケーシングとチュービングと
の両方の腐食予防になる。しかしこの防食剤あるいは他 の気化性防食剤を使用して得られた防食の程度をきめる 迅速手段はない。迅速というのはゆっくりとした時間の かかる失敗の記録と比較してである。

失策は次の三つの方法の一つで十分修理される。

（1）セメントまたはプラスチックを漏水口に圧入す る。

（2）わずかに小口径の内管の敷設

（3）ケーシングの腐食した部分を切り取って引出し， 新しい部分を補充して casing bowl または patchでも って古いパイプに取付ける。

第 1 の方法はパイプが腐食されやすい状態にあるの で，圧力によって次々に穴があくことがあるのだが，最 も普通に行われている処置である。ケーシングの内管の 設置は多くの油井は最初から $5 \frac{1}{1}{ }_{2}$ in のパイプが設置され ているので不可能なことが多い。

第 3 の方法は Permian Basin 地域では地層の中に厚 い塩水層が広がっていて，掘さく時から異常に穴の大き な井戸となっていて少々危険である。というのはケーシ ングとかチュービングの設置用セメントの必要量を計画 時の計算量よりも多くされることはまずないので，多く のパイプは水平方向から保持されてまちまちの方向の張 力とか圧力を受けながら大塩水層にむきだしでぶらさげ られている。このような支えもない大きな穴の中に置か れて起った失策なので他のケーシングもひどく傷んでい て引出してパイプの一端をそろえても他端がきれいに並 ばない。この場合に，もしも経済状態が許すならば油井 を放棄するとかあるいは再掘さくするとか指示されるの だが，普通内管を設置し，地表にセメントを塗って修理 している。本地域でのケーシングの失策の修理費用はト ラブルが起らなければ平均 25,000 ドルであるが, パッ カーの設置は 1,000 ドルですむ。

\section{マグノリア, アーカンソー地域}

マグノリアやアーカンソーのごとく酸性の原油を産出 する地域のケーシングの失策は西テキサスーニューメキ シコ地域における場合と非常に似ている。この地域につ いては Bailey と Crowell ${ }^{10}$ とょって十分検討されてい る。

\section{カンサス西部地域}

カンサスとイリノイ地域におけるケーシングの失策は 意外に激しい。これは二つの個 々の条件下に起ってい る。カンサスの Bemis-Shutts と Iuki-Carmi 油田 に拈ける多くの失策は西テキサスーニューメキシコ地域 に扮けるごとく，蒸気部分中の酸性ガスの内面侵食によ って起っている。これに反して Trapp, Dorr, Kreuger および Movel 油田における多数の失策は Dakota 砂層 の腐食性の水によるケーシングの外面侵食の結果でむし 
ろ深さが浅い所で起っている。これらの失策は平均費用 3,000ドルでセメントを圧入することによって通常修理 される。陰極防食はこの地域にて多くのオペレーターに よって応用されている。

\section{カルフォルニア地域}

Doig と Wachter ${ }^{11}$ はカルフォルニアの Ventura 油 田における失策について詳細に報告している。多方面に 亘る調査と腐食原因となる因子を次々と除いてみて，は じめて失策はバクテリヤの侵食によるとした。バクテリ ヤの種類の中で硫酸塩を還元する変種がケーシングと接 触している腐食生成物の中から分離された。高アルカリ 環境がバクテリヤの活動能力を弱めて殺すことがよく知 られているので，掘さく中の井戸全部に失策を防ぐ標準 的方法として高アルカリ泥漿の使用が行われている。け れどもこの高アルカリ泥漿の使用が既存の油井のバクテ リヤ侵食防止の解決策にはならない。

\section{他の地域}

最近あるオペレーターが南部テキサスーメキシコ湾地 域の Jim Hogg 郡のコロラド油田におけるケーシング 失策数の異常さを報告している。これは微生物による侵 食の重大さをますます認知させる。この地域は 1939 年 に発見され，約 $3,200 \mathrm{ft}$ の深さから塩水がほとんどない かまたは全然含まない API $46^{\circ}$ の良質な原油を産出し ている。

データによるとケーシングの失策が 1,450 から 1,550 $\mathrm{ft}$ の深さで 9 カ所起きている。送油管電流測定および ケーシング電圧図の結果からこの原因は表面電流および 地表電流でないことがわかった。

油井 1 本を犠牲にして, 研究のために $1,600 \mathrm{ft}$ の長さ までケーシングの回収を試みた。けれどる不幸にして $1,128 \mathrm{ft}$ (28 本) のみが回収された。ケーシングの内側 は本質的に新しいものとなんら変っていない。外側は頭 部 4 本を除いて硫化第一鉄を含む緑がかった褐色の鉱泥 が付いていた。その厚さは乾いた状態で $1 / 4$ in ああり， この中には硫酸塩還元バクテリヤの存在することが実験 により認められた。鉱泥を除去すると硫酸塩還元バクテ リヤの作用によって腐食された跡がはっきりと現われて いる。

\section{失策防止手段についての提㭉}

ケーシングの腐食は置かれている経済状態を正しく考 慮するとともに油井の制御と安全性の点から調べなけれ ばならない。ケーシングの漏れを油田が活動している間 に早く見つ汁るべく大いに努力をし使用している金属が なくなる前に予防方法とか改良方法を行う。ケーシング の腐食の問題と取組んでいる現場腐食技術者のために次 のごとく提案をする。

（1）腐食の点から泥璘とかセメントの塗込又の満足す
ベき計画を採用するために油田の幼年時代に新油田の腐 食についての特性を調べておく。

（2）予備調査で不必要であるといわれないかぎり新し い井戸全部の送油管に絶縁フランシを完全に付ける。

(3) 送油管電流調查とか埋蔵量とかから絶縁フランシ を付けた方が経済的なら古い油田にてもそれを取付け る。

(4) ケーシングの失策が起っている所でケーシングの 回収ができるなら，取出した所で直らにケーシングの検 査が行えるよ5に資格のある腐食技術者を置くこと。

（5）腐食が起っている油井に気化性および不気化性抑 制剂を十分に使用する。

（6）腐食関係の検査を取出された地中装 置全部に行 い，損傷した装置についての記録およびその費用のテー タをしっかりとととのえる。

（7）穴をあけたチュービングカップリングとオリフィ スボタンの使用をやめ, ガスリフトの全部の弁に逆流ど め弁（reverse check valve）を取付ける。

\section{結論}

石油および天然ガスを産出している井戸のケーシング パイプの腐食問題の重大性はごく最近認識されだしたも のである。腐食による失策の原因は環境因子の徹底的研 究によって大低つきとめ得る。ケーシングの外側の状態 をチェックする装置が十分とはいえないが，その他の場 合には適当な“装置”がケーシング腐食問題の研究に役 立っている。多くの油田にて明らかに損失を少なくして いる腐食防止手段は綿密に計画された，泥等拉よびセメ ント塗込みとかケーシングの内面の防食のための腐食抑 制㶡の使用および表面電流の流れを最小にする絶縁フラ ンジの使用等である。腐食防止の手段としてはこの他院 極防食とか高アルカリ泥漿の配置等研究すべき問題が多 W。

\section{交献}

1) United States Bureau of Mines Data

2) R.F. Hadley : Petroleum Engineer, 2, No.6, 171 176; No. $7,112,114,116(1940)$

3) R. L. Starkey \& K.M. Wight : Corrosion, 3, No.5, 227 232 (1947) May

4) E.S. Bastin et. al: Bulletin of American Association of Petroleum Geologists, 10, Part II, 1270 (1926)

5) E. Beerstecher:J. Petroleum Microbiology, Elsevier Press, Inc. (1954)

6) S. P. Ewing \& J.F. Bayhi : Corrosion, 4, 264 286 (1948) Jun e

7) U.R. Evans, L.C. Bannister \& S.D. Britton : Proc. Royal Soc., 131 A, 367 (1931)

8) J.D. Sudbury, J.E. Landers \& D.A. Shock: External Casing Corrosion Control.Paper presented at Fall meeting of Petroleum Branch, AIME, San Antonio, Texas. (1954) Oct. 19.

9) R.E. Hammond \& S.P. Ewing : World Oil, 154 158 (1941) Feb.

10) T.D. Bailey \& A.M. Crowell : Oil and Gas J., 31 34 (1942) Oct. 15

11) K. Doig \& A. Wachter : Corrosion, 7, No. 7, 212 224 (1951) July 